\title{
Proteomics of Juvenile Senegal Sole (Solea senegalensis) Affected by Gas Bubble Disease in Hyperoxygenated Ponds
}

\author{
E. Salas-Leiton • B. Cánovas-Conesa $\cdot$ R. Zerolo • \\ J. López-Barea • J. P. Cañavate • J. Alhama
}

Published online: 6 May 2009

(C) Springer Science + Business Media, LLC 2009

\section{Erratum to: Mar Biotechnol \\ DOI 10.1007/s10126-008-9168-8}

In the original version of this article, there were some errors on the citation of figure components in section "Identification of Differentially Expressed Proteins" and in Figs. 3 and 4 legends.

The second sentence of section "Identification of Differentially Expressed Proteins" should read:

In gill, only RKIP (spot 8) was most intense in GBDaffected animals without symptoms, while the other seven identified proteins, $\beta$-ACT (spot 3), RKIP (spot 5), CaM, $\beta$-TBB, $\alpha$-TPM/MLC1, $\beta$-ACT (spot 22), and GAPDH, were most intense in affected fish with symptoms, most of them following expression pattern I.

Correct Figs. 3 and 4 legends are given here.

The online version of the original article can be found at http://dx.doi. org/10.1007/s10126-008-9168-8.

E. Salas-Leiton · R. Zerolo • J. P. Cañavate

IFAPA Centro El Toruño, Junta de Andalucía,

Apartado 16,

11500 El Puerto de Santa María, Cádiz, Spain

B. Cánovas-Conesa $\cdot J$. López-Barea $\cdot J$. Alhama $(\bowtie)$

Departamento de Bioquímica y Biología Molecular,

Universidad de Córdoba,

Edificio S. Ochoa,

14071 Córdoba, Spain

e-mail: bb2alcaj@uco.es 

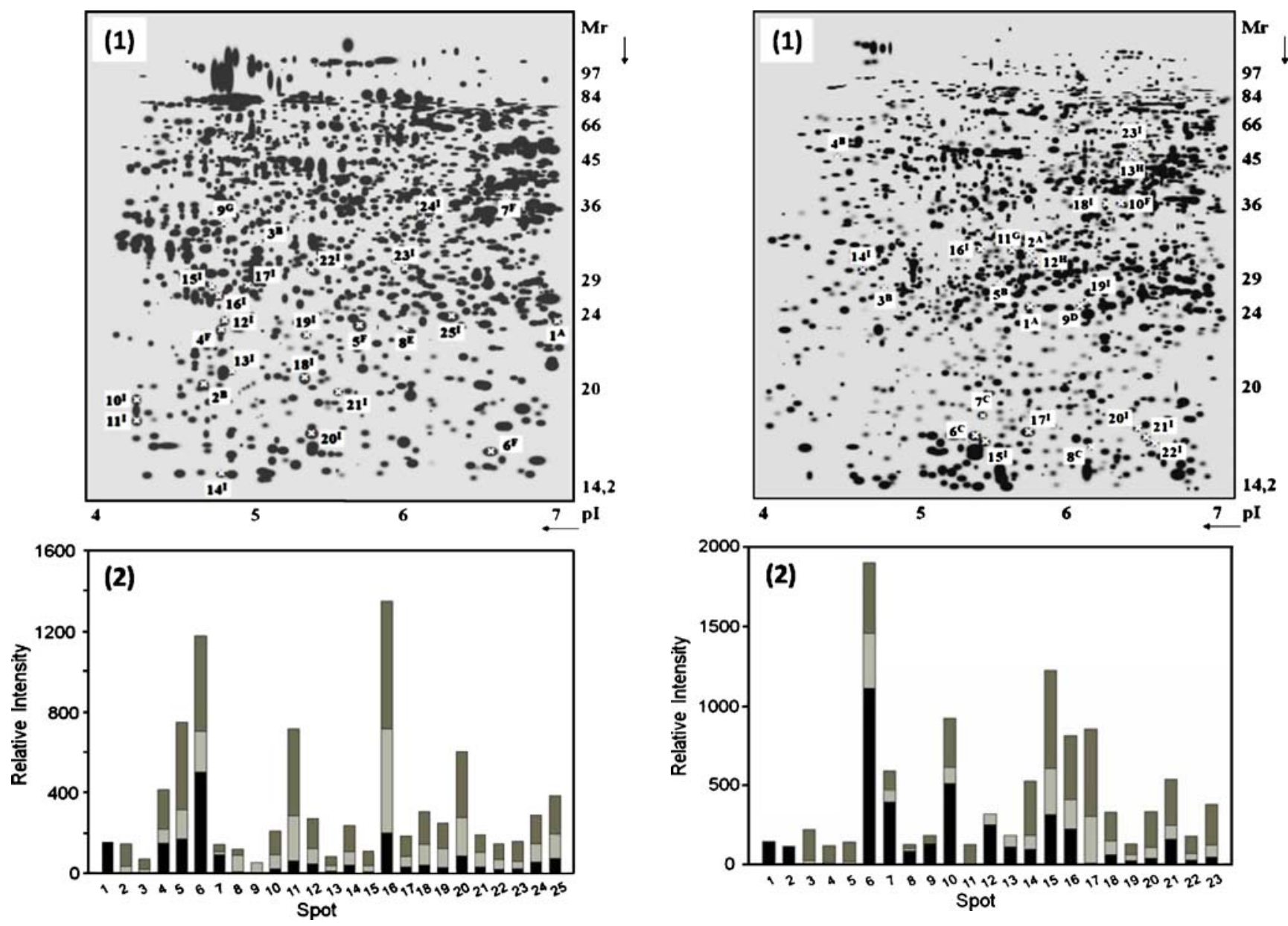

Fig. 31 Master gel of gill cytosolic proteins with 25 spots characteristic of six expression types: $(A)$ present only and $(B)$ absent in healthy fish. $(E)$ Increased and $(F)$ diminished in affected asymptomatic fish. $(G)$ Present only in affected fish with external symptoms. (I) Increased in affected fish with external symptoms. 2 Relative intensities of the proteins included in the master gel in the three statuses studied: $\square$ healthy control fish; $\square$ GBD-affected asymptomatic animals; $\square$ GBD-affected fish with visible symptoms

Fig. 41 Master gel of liver cytosolic proteins with 23 spots characteristics of eight expression types: $(A)$ present, $(B)$ absent, and $(C)$ increased in healthy fish. $(D)$ Absent and $(F)$ diminished in affected asymptomatic fish. $(G)$ Present, $(H)$ absent, and $(I)$ increased in affected fish with external symptoms. 2 Relative intensities of proteins included in the master gel in the three health statuses studied: healthy control fish; $\square$ GBD-affected asymptomatic animals; GBD-affected fish with visible symptoms 